\title{
THE SPECIAL UTILIZATION OF CASTLES IN TOURISM - FESTIVALS IN THE HERITAGE SITES
}

\begin{abstract}
Judit Péterfi ${ }^{1}$
Abstract: In Hungary, there are a large number of built heritage. Of these, this current research focuses on the castles. Nowadays castles can be filled with many functions, such as schools, common lodging houses, hospitals or residential buildings. The most optimal form of usage is tourism utilization, such as museums, hotels, event venues. Organizing festivals is also a tool for this, it generates revenue for the castle, and makes it widely available to enhance the visibility and acquaintance of the venues. A festival is also intended to suffice the needs of tourists and local people, and these castles provide a suitable scene for this. Thus, the current research aims to present and evaluate the form of utilization of castles in which festivals are organized. The study aims to answer the research question through several case studies, that festivals contribute to the survival of the castles as they generate revenue and create more attractive destinations. To answer this question, a primary research method is needed where interviews with the owners of the venues and the festival directors come to the fore. In addition, the available secondary data are required that numerical support the generated revenue and number of visitors alike. In the end, the research will be carried out where both the utilization of the castles and the festival tourism will be of paramount importance and a joint impact assessment will be implemented.
\end{abstract}

Keywords: castle utilization, tourism, festival, heritage

\section{INTRODUCTION}

These days a special attention is paid in Hungary to monument buildings and their utilisation. Utilisation can happen in several ways, in social care, education, and as a residential place or touristic venue. Accordingly, these buildings are important parts of heritage tourism as well. The utilisation of the buildings - besides carrying an economic potential - is also important in monument protection, as this way buildings are preserved. In Hungary, in line with the expectations of the European Union, a great deal of attention is paid to built heritage, and a number of (tenderable) resources are available for the preservation of the buildings and their development.

This research deals with the use of the castles in tourism in which special attention is paid to the buildings, but only as venues of festivals. The aim of the research is to introduce and evaluate this kind of utilisation of the castles. Thus, the research

\footnotetext{
${ }^{1}$ MSc, University of Pécs - Institution of Geography and Earth Sciences, juditpj03@gmail.com
} 
question is whether festivals contribute to the survival of the castles as they generate revenue and create more attractive destinations.

The interdisciplinary character of the issue is proven by the fact that both castles and festivals are integral parts of tourism. In this field we must mention the activity by Victor Turner, as he summarised the theoretical foundations of festivals and tourism (Turner, 2002). Urry, on the other hand, approached the relationship system of tourism and festivals from the practical side, on the basis that gaining experiences at tourism destinations is the main motivation when visiting festivals (Urry, 2002). Several researchers have also been active in the area of cultural heritage and monuments (including, among others, Marosi E. 1996 and Deme P. 2007), but the work by Gábor Sonkoly must be selectively mentioned: he created the conceptual and spatial system of cultural heritages (Sonkoly G. 2000).

The effects of the utilisation of castles - having an impact on both the economy and settlements - are in the research focus of several researchers, including, among others, Adrienn Nagy (2010, 2013), Csaba Fekete J. (2016) - and also me on the basis of these activities (Péterfi J. 2015, 2017).

\section{METHODS}

Answering the research question requires methods in which both the processing of secondary data and the collection of primary information are emphasised. As regards secondary data available, we have no access to data concerning the numbers of visitors to festivals. Statistical databases only contain data at aggregate settlement level, and so - and also because there is a significant volume of non-measurable demand, due to some festivals that are free of charge - I was not able to use these pieces on information concerning visitor numbers. Although the organisers possess estimated or exactly measured data, they usually do not make them available, or simply deny the provision of data. Consequently, under the heading 'secondary data' I mean programme offer available on the internet, technical literature, and the relevant legal regulations. I was able to use as a primary source, on the other hand, self-made interviews with festival organisers and owners of the castles. The deficiency of my research is to be found in non-available secondary data and in the missing questionnaire survey of the guests. The literature available, however, eliminates much of the deficiency of this present paper. As the literature mentioned - including the doctoral thesis of János Zoltán Szabó from 2011 - examined a number of cultural festivals, the demonstration of the festivals in my paper can be taken as a kind of supplementation, upgrading and correction. The analysis of festivals organised in Acsa and Nagykovácsi are focal parts of the research, correlating to all other festival in Hungary that are organised in castles or monument buildings. During the interviews made I had the chance to talk to the organiser in 
Acsa (Attila Alföldi), but I was unable, unfortunately, to get in touch with the owner of the castle (National Wealth Manager). However, as it is a castle in the ownership of a larger organisation, the viewpoint of the owner is known. In Nagykovácsi I was able to interview the owner of the castle (Hungarian Scout Association) as well, and so interests of the owners could also be focused on during the research. On the basis of the primary data available I made an evaluation of pros and cons in the settlements, which is the central part of my research.

\section{RESULTS}

Castles and their utilisation

On the basis of the literature available, the first task of the paper is to clarify the relevant concepts. The first such concept in the relationship between castles and tourism is castle itself. "Today, we describe mansion/castle as a residence of the former aristocracy, built in rural, parked surroundings, which has a large-scale, complex layout and is a varied, picturesque massive residential building" (Koppány, 1974). These buildings belong to the category of our cultural heritage because inheritance value is equally formed, as a cultural value and additionally, a built, tangible heritage of ours. These buildings can be found in several places in Hungary, owing to the colourful historical past of the country. The primary objective of the construction of castles varied across the different ages, and so the fortress castles and mansions that we inherited are all parts of the built heritage of Hungary. A brief historical overview of the buildings examined is also necessary for us to understand present processes, including why these buildings are suitable venues for different festivals.

Due to past events the number of Hungarian mansions has diminished over the years. The first major changes took place during World War II. The war caused enormous damages to the buildings, not only because of the military actions and bombardments but because of the fact that they had been subject to war operations and served as military objects (armoury, base etc.) for many years. Even those buildings that survived were doomed, once the process of collectivisation started in Hungary (just like in other countries under Soviet influence). Before the war, more than 1,500 castles and mansions were maintained in the country and supplied by their own land, but after the war, these buildings were given to state ownership, with many damaged and plundered lands and with approximately $4,600 \mathrm{~km}^{2}$ of moor parks and gardens, which was not sustainable (Fekete, 2016).

Unfortunately, the state gave these buildings new functions that the mansions were totally incompatible with. They became cemeteries, offices, military headquarters and social care homes. We could find numerous examples when the government 
entirely left some mansions to their own devices, unchecked and after some years, the buildings were on the edge of total decay, but there are also pieces of evidence for cases when the estates lost their former beauty, due to the constructions required for their new functions, but their survival was at least assured.

On the other hand, these partly regrettable events also led to the birth of the Hungarian monument protection in the middle of the $20^{\text {th }}$ century. One of the first such organisations, The National Monument Protection Inspectorate, preserved approximately 800 castles and mansions, out of which many have been disclaimed due to severe deterioration (National Monumental Inspectorate, 1960). With the improvement of the economic situation, some improper functions were removed from several mansions, and usage of the building became limited because of the preservation of the monument.

These challenges brought the first mansion programme to life in 1981, namely the Economic Committee Mansion Programme, which included the restoration of 72 monuments - out of which 22 were mansions (Petravich, 1996). In 1992 the State Stewardship of the Monuments (MÁG) became the trustee of state-owned mansions and set up a programme the aim of which was to transform the mansions into a tourist scene (Fekete, 2016). In 1997 the list of monuments was enlarged as part of the Act No. LIV of 1997 on Monument Preservation, the Monument 2000 was drawn up and an archive of the exploitable heritages was produced. In 2000, the project of the National Mansion Programme was adopted and the Millennium Mansion Programme provided additional resources for the MÁG (Berger, 2001). The Mansion Programme in 2004 was a similar measure, where there was already an attempt to involve private capital with state aid, with the aim of opening the reestablished mansions to the public (Mansion Programme I, 2004). However, it was not the largest change that year. Hungary gained membership to the EU, which basically changed the conversion trends of the mansions on the financing side.

As for the utilisation of the castles today, it can be said that due to the monumental nature of castles, they can be perfect for housing ethnographic museums and exhibitions. This form of conversion is the most suitable, since the building does not deteriorate any further this way and it can preserve its heritage value. Of course, more forms of usage are suitable for castles and mansions, such as cultural houses, archives, or event centres. Turning mansions into tourist destinations (mansion hotels) can perhaps be regarded the most appropriate form of conversion since it serves a similar function as their original function. A cost-effective conversion plan may, in many cases, be a hindering factor in tourism utilisation, as the premises cannot be taken apart, rebuilt, only minor modifications can be made, no drastic adjustments are possible. Of course, we must not forget about mansion conversions made for social purposes, where mansions are turned into children's homes, psychiatric institutions, hospitals and educational establishments, such as the 
Pallavicini mansion, located in Somogy county, which was turned into a teaching hospital. There are some obvious problems with that sort of conversion, for example, it makes the mansion more difficult to visit and its maintenance becomes much more expensive. When converting the building into a hospital, the high level of hygienic expectations, which often hindered this type of conversion, became a separate obstacle (Péterfi, 2015).

On the ground of these main categories (tourist, social, educational and other, for example residential), the organisation of festivals in castles is definitely in the framework of their use in tourism, the analysis of which form of utilisation will be done in this paper.

\section{Festivals}

In the clarification of the concept of festivals, among others Alessandro Falassi made a remarkable impact. He defined the essence of festivals as follows: "In the social sciences, festival commonly means a periodic celebration composed of a multiplicity of ritual forms and events, directly or indirectly affecting all members of a community and explicitly or implicitly showing the basic values, the ideology, and the worldview that are shared by community members and are the basis of their social identity" (Falassi, 1997). Falassi went on to make the definition more accurate, in which he emphasised that the essence of festivals is in repetition, in celebration, in rituals, in the basic feeling of the community and also in identity. In Hungary we find several types of festivals (like art festivals; amateur art and "ascending competitions"; gastronomic festivals; other non-artistic festivals etc.) and almost all of the Hungarian settlements can boast of one or another type of festival (e.g. Village Day).

The history of the birth of modern times cultural festivals started at Woodstock, especially if we are looking for the predecessors of today's popular music festivals (Sziget, VOLT, Sound etc.). But the festival mentioned, organised in 1969 near New York, made a lasting impact not only in its own style but it also founded the model of festivals. It suffered from organisational problems, ended with a deficit as a negative effect of entrance free of charge, but it also created a sample for celebrating community building, recreation and the gaining of new experiences. The iconic Woodstock festival can also be taken as a mild rebellion against the system (open consumption of drugs, hippies), still it contributed to the birth of cultural festivals. The first art festival ion Hungary was the Szeged Open Air Festival in 1931, although the Busó Festival had already been born in the 1700s, as the oldest cultural festival surviving from a folk habit with traditional historical past (Szabó J. Z. 2011). If we want to break festivals down into several groups, we can create a triple system: the group of entertainment events, community events and 
competitions/contests. Breaking down community events further we can talk about social programmes, holidays, folk holidays, village days and church festivals, so they make a quite mixed category (Bárdosi et al. 2004). The typically one-day events like village days and church festivals are not registered by literature in the cultural festival category, as not all of the necessary conditions have been created yet (Szabó J. Z. 2011). I can only partially agree with this statement, as in the background of the organisation of village days and church festivals we usually find the cult of the patron saint of the respective settlement, or other religious reasons, and so they can be fully matched with cultural heritage and the preservation of culture, accordingly they can be considered as cultural festivals. Village days and smaller-scale events are also important because both festivals analysed in this paper belong to this category, and also because the similar researches implemented usually neglect smaller-scale events, and so this paper can shed a new light on the research of festivals by the introduction of the case studies.

The case studies

An irreplaceable part of the paper is the acquisition and use of primary data. For this purpose I made two case studies, including making interviews in Acsa and Nagykovácsi. The reasons why I chose these two villages is the large number of data available on the internet about their events and also about their castles, furthermore, the kind assistance of the organisers and the owners allowed me to access background information that are indispensable for the research. As I have already mentioned, the owner of the castle situated in Acsa is National Wealth Manager, whom I was unable to contact, but their viewpoint and interest representation, being a state organ, is clear-cut. We cannot neglect a brief introduction of the settlements and the castles in this paper. 


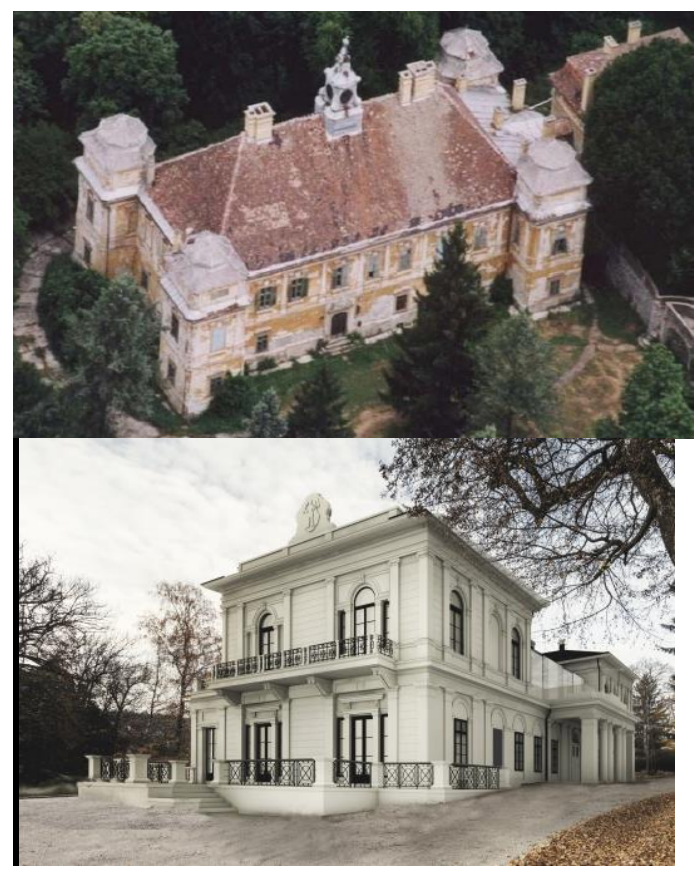

Fig. 1: Prónay Castle

Source: https://www.szepmagyarorszag.hu/ kastely.hu/
Fig. 2: Teleki-Tisza Castle Source: https://teleki-tisza-

Acsa is a settlement with 1,416 inhabitants in Pest county where traditional habits are very important. The village is home to Prónay Castle (Fig. 1), a building erected in 1740 in baroque style and now protected by the Act on Monument Protection. The castle, unfortunately, cannot be visited (it has no function), it is open to visitors during the times of events, only. The building was awarded support from the GINOP (Gazdaságfejlesztési és Innovációs Operatív Program, Economic Development and Innovation Operational Programme) announced in 2015, and so renovation works are going to be started soon, thank to the European Union and the Government of Hungary (http://www.acsa.hu/).

Nagykovácsi is a settlement with 7,255 dwellers also in Pest county. An interesting feature is the lack of passing traffic: it is a dead-end settlement. The Teleki-Tisza Castle that can be found here (Fig. 2) was built in classicist style in 1840. This building too is under the effect of the Act on Monument Protection and cannot be visited, except for the times when events are held. The castle, anyway, is a totally renewed building, refurbished in 2018, using finances from the European Union support through KEOP (Környezet és Energia Operatív Program, i.e. Environment and Energy Operational Programme). It is owned by the Hungarian Scout Association that operates the castle as a non-public event centre - for conferences, wedding ceremonies and scout programmes (http://nagykovacsi.hu/varazskastely). 
The two castles in the focus of the paper are thus different not only in ownership but also in the functions and conditions of the buildings, still they are similar to each other, as both buildings are home to local programmes: in Acsa the so-called "Ganca day" (ganca is a special local dish), in Nagykovácsi the Varázskastély Fesztivál (Magic Castle Festival) is implemented (Fig. 3).

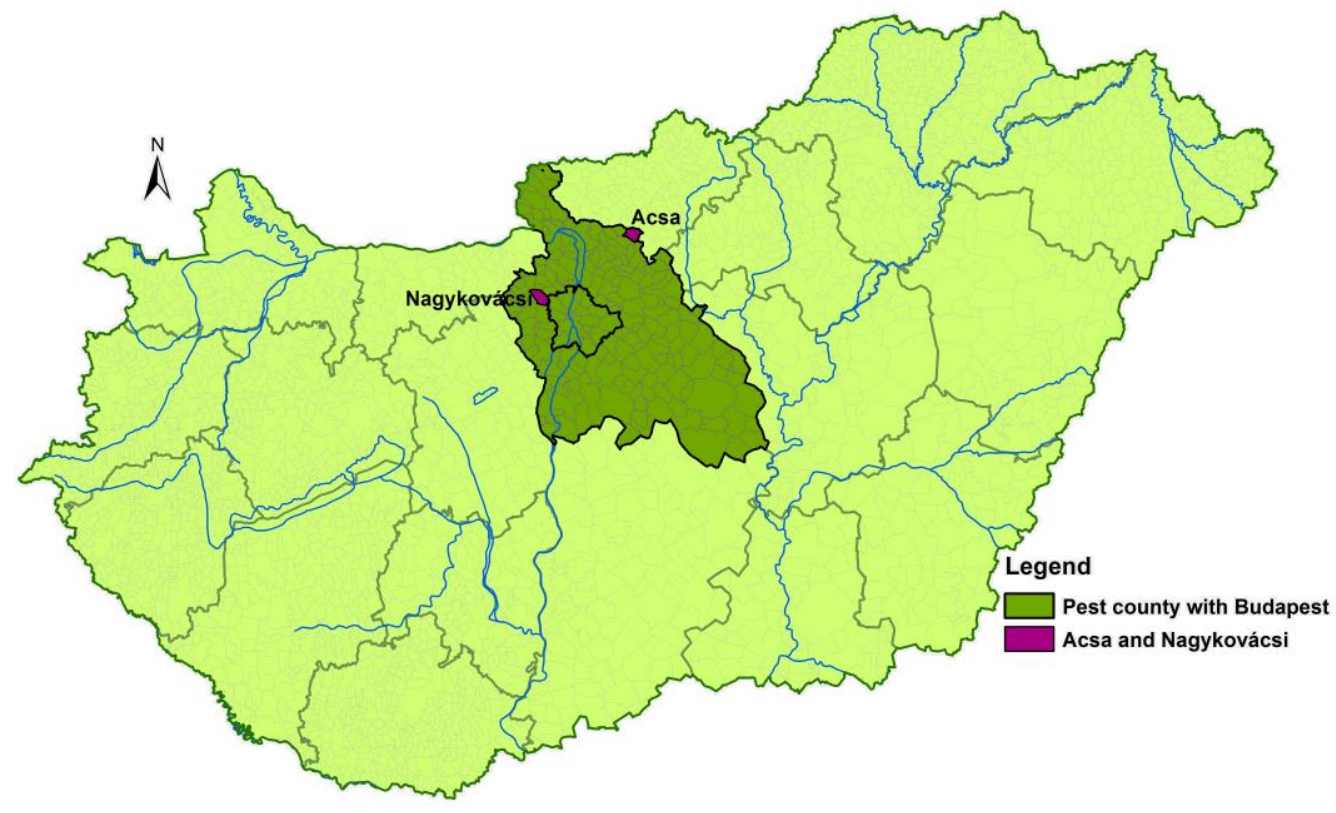

Fig. 3: The geographical positions of Acsa and Nagykovácsi

Source: edited by the author, 2018

Festivals in the heritage sites

My primary research question was how much a heritage site (a castle) could be suitable for the organisation of a festival. I sought the answer to this question in the technical literature in the first place and on the basis of this I looked at the relationship between the festivals analysed in the case studies and the castles. Klaic said in 2002 that "[...]Afterwards, festivals rediscovered and re-appropriated hundreds of churches, castles, fortresses and other places of cultural heritage to infuse them with traditional and contemporary arts, to reveal them as places of collective memory" (Klaic, 2002). On this ground festivals held in castles are positive phenomena, filling up the heritage sites with arts and thereby turning them into a place that contributes to the strengthening of collective memories and community identity.

Parallel to this, Vabres said that "A place without projects becomes extinct" (M.R.D. Vabres 2010). In addition to preserving the cultural heritage, it is the responsibility 
of the maintainers to make known the inheritance and to involve them in educational and cultural processes. Concerning this, my preliminary idea was that this way of the utilisation of castles may bring about several advantages, including becoming a tourism attraction, extension of the tourism season, growing interest and attention, better recognition of the place and the strengthening of the connections of stakeholders.

In addition, I also presumed before the start of the primary research that the interests of the actors in the network were different. In my opinion, the organisers would like to have a good programme in a beautiful and cultural environment, but the building itself is not a significant factor for them (from preservation and amortisation aspect). As regards the owners, I assumed that they expected more recognition of the castles and higher revenues, but for them the building itself and its protection matter much more. The other interesting issue is the financial background of these events. Such festivals are usually organised with state and local support, often also including volunteers. This was also the case at the festivals in the case studies; also, revenue generation was not among the prime objectives of the organisers. Actors of the festivals examined were not only the owners, the organisers and the supporters but also the visitors (being the most important participants in the network and mainly local inhabitants), artists, catering, service and all other staff.

My preliminary assumptions and the findings of the technical literature were not much modified by what I heard in the interviews, but I was given several interesting facts and data that allowed the making of a pro and cons examination from both sides. First I wanted to hear the opinion of the owners, which is best summarised in Table 1 .

Table 1: Pros and cons from the owner's point of view

\begin{tabular}{|c|c|}
\hline Pros & Cons \\
\hline $\begin{array}{l}\text { - Generally the castle cannot be } \\
\text { visited but at the time of the } \\
\text { festival it is open }\end{array}$ & $\begin{array}{l}\text { - Amortisation (stage construction, } \\
\text { garbage) }\end{array}$ \\
\hline $\begin{array}{l}\text { - } \begin{array}{l}\text { Better relationship with the local } \\
\text { management }\end{array}\end{array}$ & $\begin{array}{l}\text { - The owners give the staff and the } \\
\text { necessary equipment }\end{array}$ \\
\hline - Growing reputation and interest & - $\quad$ Feeling a little political pressure \\
\hline - $\quad$ Returning guests & - $\quad$ No revenue (free festivals) \\
\hline - Charity & - Complicated organising work \\
\hline
\end{tabular}

Source: edited by the author, using the interviews, 2018

As it can be seen from the summary of the table, offering a castle as the venue of a festival brings several negative and positive consequences to the owners. As said by the owner of the castle that can be found in Nagykovácsi, the only reason why they 
allow the programme to be organised there (Magic Castle Festival) is the intention to have a good relationship with the local leaders and so they experience this as a kind of political pressure. This festival is organised by the municipal selfgovernment that pays a minimum amount of rent. No other similar public event than this festival is held in the castle. The amount of rent does not cover the expenses like the costs of the staff and the furniture, protection of the venue and hiring animators, and so - also because entrance to the festival is free - the festival generates no revenue for the castle. The festival does not contribute to the utilisation of the castle (external catering businesses, handicraftsmen and city restaurants are present), it has more disadvantages: the stage erected is a stress for the park of the castle, as are littering, the $20 \mathrm{~nm}^{2}$ bouncy castle and the large number of trucks. Visitors of the festival are usually local residents (who are shown around free of charge) who may return to the café several times but do not contribute much to the profit of the castle, the purpose of the visitors from all over the country is the sheer visit to the building. To summarise the opinion of the owners we can say that the organisation of such an event in the castle and its park is only worth it if done by the owners themselves and they can charge the visitors a minimum entrance fee, because it is a great responsibility and work to let so many visitors into a castle, especially one that has just been totally renewed. So we may reasonably ask whether the original function of the castle is compatible with the festivals or not.

Table 2: Pros and cons from the organiser's point of view

\begin{tabular}{|l|ll|}
\hline \multicolumn{1}{|c|}{ Pros } & \multicolumn{1}{c|}{ Cons } \\
\hline $\begin{array}{l}\text { Generally the castle cannot be } \\
\text { visited but at the time of the } \\
\text { festival it is open }\end{array}$ & - $\begin{array}{l}\text { Keeping in mind the interests of } \\
\text { the owners }\end{array}$ \\
\hline $\begin{array}{l}\text { Better relationship with the } \\
\text { owners }\end{array}$ & - $\begin{array}{l}\text { Lease payment and take care of } \\
\text { the service and some equipment }\end{array}$ \\
\hline - A nice environment & - & Complicated organising work \\
\hline Interested and returning guests & - & No revenue (free festivals) \\
\hline
\end{tabular}

Source: edited by the author, using the interviews, 2018

The second table (Table 2) summarises the advantages and disadvantages as seen by the organisers. What I have already taken as positive effect as seen by the owners and what is positive concerning the situation of the castles as well is the fact that buildings are open to the visitors for the time of the programmes. Another definite advantage is the strengthening of cooperation between stakeholders and the local inhabitants. Further positive effects that must be mentioned include - verifying my previous hypothesis - is the beautiful and picturesque setting offered by the castle 
that raises the prestige of the festivals. Organisers see it as an advantage that programmes may increase interest in the castle and also the programme, so they expect to win returning guests. The most important advantage - besides providing a suitable setting for events - is of course the minimisation of financial inputs, which is usually realised because they can rent the castle for a minimum amount of money (or free of charge), supplemented with state supports and offerings.

The disadvantages on the side of the organisers are also clear-cut: they include the difficulties of cooperation with the owners (legal obligations and individual interests must be continuously considered and reconciled), and there is a complicated organisational activity behind the implementation of such an event. If rent must also be paid, this is another disadvantage for organisers who also have to provide services and equipment. The protection of the environment is another difficulty many times, as for the organisers the castle is not a protected monument building but a high-quality venue where the environment must be rigorously taken care of. The most serious disadvantage - as in the case of owner as well - is the lack of revenues, as these are festival free for everyone and expenses are usually covered from supports.

The organiser of festival held in Acsa emphasised, besides the facts mentioned above, that the Ganca Festival, celebrating its jubilee, is visited by 350 visitors this year, $80 \%$ of whom are local inhabitants. Financial support is provided by the financing of the municipality, offerings of local entrepreneurs and retailers, public workers, local non-governmental organisations and the contribution of two ethnic minority selfgovernments. When placing the festival in the castle the primary motivation for them was to have the event in a beautiful setting in a prestigious place, the milieu of the castle was attractive, and they also emphasised that the owner (National Wealth Manager, Buda Castle Property Management Ltd.) allows the utilisation but does not impose any restrictions other than meeting the legal obligations concerning the protection of the building. During the interview it also turned out that the function of the castle and the goal of the festival cannot be reconciled at all, and the event does not contribute the least to the utilisation of the castle. My research question then may be reasonably asked again: what consequences a festival held in such a monument setting has, i.e. the enrichment of the castle with such functions contributes to the adequate utilisation of the castle or not.

The reviews of the literature and the findings of field work, interviews made it clear for me that the utilisation of castles in this way does not contribute to the maintenance of the buildings. On the other hand, the buildings and the festival have a milieu that promotes the propaganda and utilisation of the buildings (if the buildings are not used already). In my opinion one of the biggest advantages may be the birth of a multilateral cooperation during the organisation of such an event among the organisers, the owners, the entrepreneurs, the non-governmental organisations, the visitors and all other participants which is unique and necessary for 
the implementation of such a festival in way that the protection of the monument building is also secured. Interests are conflicted many times, but as long as the most important aspect for all stakeholders is to keep the castle and the park around it intact (but also open to the public), this is a feasible way of utilisation.

As regards the future of the festivals in the two case studies and of the castles, the situation is more complicated, because - as I have already mentioned - the TelekiTisza Castle (in Nagykovácsi) was completely renewed this year, and so the owner (Hungarian Scout Association) is not happy about this way of utilisation. The Prónay Castle (in Acsa) is going to be completely renewed in the near future, which may prevent the organisation of the festival later on. I find it important that each participant should do their best to find solution acceptable for all, in a way that is not disadvantageous for the guests of the festivals (and for the protected buildings either).

\section{CONCLUSION}

The ultimate achievement of the paper is the definition of positive and negative effects in the process of the utilisation of castles as festival venues. During the research the primary survey method of interviewing had an outstanding significance. These interviews provided data that demonstrated the conflicting interests among the different stakeholders. When looking for the answers to the research questions specified in the paper, new results have been achieved which reinforce the fact that any kind of utilisation of castles contributes to the preservation of the built heritage, and that the most suitable way of their utilisation is tourism.

In addition, the paper makes statements the verification of which is justified by the interviews, but the involvement of further stakeholders (visitors) in the research is also necessary. During further research, the examination of the statement that the organisation of festivals in monument setting will generate revenues and create a more attractive destination from other aspects might be suitable for the reconciliation of the conflicting interests of the interviewees.

The specialty of the paper is the examination of festivals that have not been analysed by academics so far, and so it deals with a new territorial aspect. Also, the assessment of the impacts of smaller-scale, one-day events is innovative.

During the research done so far, the paper demonstrated, mostly agreeing with the statements of the literature, the situation of castles and festivals in Hungary and the relationship between them. Besides the complicated organisational activities of festivals held in heritage sites the paper also highlighted conflicting interests of organisers and owners. The findings of the interviews made it clear that owners are reluctant to lease their buildings for such purposes, in fear of high amortisation danger and due to the lack of revenue, and so for them the primary goal is the 
protection of the castle. In addition we can also see that for organisers the venue is important because they make the festival more prestigious; they do not care much about the protection of the castle building, though.

Further research tasks include the discovery or invention of good practice, as the multilateral cooperation is in vain if the present attitude of the owners is determined by some involuntariness. Also, the research should be extended to local inhabitants and visitors as well, in order to find how important the venue is for them when deciding to visit a festival. Examinations should be extended to other fields as well, in order to get an even more comprehensive picture of festivals organised in heritage sites: castles.

\section{Acknowledgements}

This publication/research has been supported by the European Union and Hungary and co-financed by the European Social Fund through the project EFOP-3.6.2-162017-00017, titled "Sustainable, intelligent and inclusive regional and city models".

\section{REFERENCES}

1. Bárdosi, M. et al. 2004. A kultúra helyzete Magyarországon. Találkozások a kultúrával 4. Budapest: Magyar Müvelődési Intézet.

2. Berger, Zs. 2001. Kastélykezelők. Figyelö XLV. évf. 47. sz. pp. 21-22.

3. Deme, P. 2007. Müemlékek, múzeumok mindenkinek? NKA kutatások 4. Budapest: Kultúrpont.

4. Falassi, A. 1997. Festival. In: Thomas A. Green (ed.) Folklore. Santa Barbara: ABC-CLIO

5. Fekete, J. Cs. 2016. A magyarországi kastélyprogramok bemutatása kitekintéssel az állami kastélyfenntartás külföldi gyakorlatára. http://www.terc.hu/documents/Kast\%C3\%A9lyprogram\%20cikk.pdf (25 Oct 2018)

6. Klaic, D. 2002. The Future of Festival Formulae. https://www.scribd.com/document/272019439/The-Future-of-FestivalFormulae-Dragan-Klaic-HFsympbackground-Paper (20 Oct 2018)

7. Koppány, T. 1974. A castellumtól a kastélyig. Müvészettörténeti Értesitö. 23 (4): pp. 285-299.

8. Marosi, E. 1996. Mûemlékvédelem - az örökség hagyományozása. In: Bardoly I.-Haris A. (eds.), A magyar mûemlékvédelem korszakai. Budapest: Országos Mûemlékvédelmi Hivatal. 
9. Nagy, A. 2010. Kastélyok turisztikai szerepe a XX. században. - In: Aubert A. - Gyuricza L. - Huszti Zs. (eds.) A kultúra turizmusa a turizmus kultúrája. PTE TTK FI - PTE IGyK GTI, Pécs.

10. Nagy, A. 2013. A kastélyhasznositás regionális jellemzöi ÉszakMagyarországon, különös tekintettel a turizmusra. PTE TTK FI, Pécs.

11. Péterfi, J. 2015. A kastélyok és kúriák hasznositása Somogy megyében a turizmus és a településfejlesztés tükrében. Pécs: PTE TTK FI.

12. Péterfi, J. 2017. A magyarországi kastélyok hasznositásának lehetöségei a pályázati rendszerek tükrében. Pécs: PTE TTK FI.

13. Petravich, A. 1996. Veszélyeztetett kastélyok és középületek helyreállítása. Magyar Müemlékvédelem 1980-1990. In. Császár L. - Hokkyné S. M. - Horler M. - Mendele F. (eds.) Budapest:Országos Műemlékvédelmi Hivatal.

14. Sonkoly, G. 2000. A kulturális örökség fogalmának értelmezési és alkalmazási szintjei. Regio - Kisebbség, politika, társadalom. 11.évf. 4.sz. pp. 45-66.

15. Szabó, J. Z. 2011. Kulturális fesztiválok, mint a müvelödés új formái. DE BTK. Debrecen.

16. Turner, V. 2002. A rituális folyamat. Budapest: Osisis.

17. Urry, J. 2002. The Tourist Gaze. London: Sage.

18. Vabres, M. R. D. 2010. Oral Communication. Heritage in the Economy Economy in Heritage conference. Fehérvárcsurgó.

19. Act No.LIV of 1997 on Monument Preservation

20. Mansion Program I. 2004

21. National Monumental Inspectorate, 1960

22. https://www.szepmagyarorszag.hu/magyar/oldalak/acsa_pronay_ujlak_kastely_ gajavolgy/ (14 Oct 2018)

23. https://teleki-tisza-kastely.hu/ (14 Oct 2018)

24. http://www.acsa.hu/index.php/26-uncategorised/751-xganca (15 Oct. 2018)

25. http://nagykovacsi.hu/varazskastely (15 Oct 2018) 